\title{
PRODUCTIVITY IMPROVEMENT OF CASTINGS, SWITCHING TO SHELL MOULD PROCESS FROM GREEN SAND MOULD PROCESS
}

\author{
Shruthi Y C $\mathbf{C}^{1}$, Ramachandra C G' ${ }^{2}$, Veerashekhar $\mathbf{M}^{3}$ \\ ${ }^{1}$ MTech Scholar, ME Department, Srinivas Institute of Technology, Valachil, Mangalore \\ ${ }^{2}$ Associate professor, ME Department, Srinivas Institute of Technology, Valachil, Mangalore \\ ${ }^{3}$ Director, Adishakthi Castings, Shimoga
}

\begin{abstract}
The creation and application of technology to monitor and control the production and delivery of products and service in casting foundries has gained importance and are necessary to sustain in competitive market conditions. Setup of the industries as applied to casting foundries need timely setup and changes to cope up with the increasing demand from the customers as foundries have great demand for the products produced, in numerous fields. In this paper various parameters of importance are improved by employing shell mould process to the castings which were previously produced by green sand mould process.
\end{abstract}

Keywords: shell mould process, Green sand mould process, foundries. $* * *$

\section{INTRODUCTION}

An object made by pouring molten metal into the mould, usually liquid metal is poured into the mould which contains a hallow cavity of desired shape, it is then allowed to solidify. The solidified part is known as casting which is removed from the mould by proper removal procedures to complete the process. Casting is one of the oldest manufacturing processes from which simple and complicated shapes can be made from any metal that can be melted. Around 6.5 million $\mathrm{kg}$ of casting are produced every year. The most common materials used for casting are grey iron, ductile iron, aluminum alloys and copper alloys.

The cast component has a shape, size, chemical composition and metallurgical microstructure which is determined by engineering decisions arrived by design engineers, pettren makers, casting engineers and manufacturing engineers along with technically well versed team who work together as a team to manufacture castings in intended time and in a cost effective manner. Castings produced may be small part of useful device or it may be the entire device. Foundry is a casting factory which equipped for making moulds, melting and handling molten metal, performing the casting process, cleaning and finishing the castings.

The two main processes upon which the present work is based on are green sand mould process and shell mould process. Green sand mould process utilizes a mould made of compressed or compacted moist sand packed around a wood or a metal pattern. Whereas shell mould process is an expendable mould casting process that uses a resin covered sand to form the mould. Sand used in both the processes has different characteristics which has impact on final mould as well as finishing. Sand used in green sand mould process contains high moisture content whereas shell mould process uses fine-grained high purity sand along with resin. Accordingly the castings taken out will be less smoothly finished bearing rough surfaces in green sand mould process and fine finished castings in shell mould process. To match with the increasing demand, industry concentrated on changing the process and accordingly the machinery setups which routed towards shell mould process from green sand mould process.

In this paper, we describe analysis and experimentation of the system for the production of castings which improves yield, quality and delivery of castings and also reduction in rate of rejection, raw materials and manual work. Analysis and experimentation will be performed and results will be compared.

\section{RELATED WORK}

There are many works carried out on castings and their types [1] the casting liquid metals to produce solid objects is a manufacturing process which has been practiced since many years, with investment castings being one of the oldest known metal shaping methods. The technique has tremendous advantages in the production of quality components and the key benefits of accuracy, versatility and integrity. In this work incorporating organic fibres into the binder improved performance and reduced shell production time and also shell thickness is improved.[2]

Reports on an improved method to evaluate both the strength and the permeability of ceramic shell specimens under high temperature conditions. [3] In order to maintain safe testing 
conditions and use lower testing pressure, a spherical wax model was used to prepare ceramic shells. Compressed air was introduced into ceramic shell specimen held at $900{ }^{\circ} \mathrm{C}$. Air flow and pressure drop across the shell wall were measured and hot permeability was calculated. Air pressure was subsequently increased and recorded up to bursting point. A hoop stress formula was used to calculate the hot strength from the bursting pressure. This very simple method is easy to implement in foundries.

\section{PROCEDURE}

As per customer requirements, foundries will manufacture different grade of castings. Present work is carried out for SG 700/2 Grade.

Providing allowances, risers sprues etc drawing according to the customer requirement is done.

\subsection{Preparation of Moulds}

AFS 75/78/80 Sand mixed with4-6\% resin is weighed as per requirement and required pattern is kept in the shell mould machine. Sand is filled properly in the pattern and it is heated to required temperature (usually $175-370^{\circ} \mathrm{C}$ ). using compressed air shell moulds are cleaned and inspected for damages[4].Moulds are heated to $180-200^{\circ} \mathrm{C}$ for $30-45^{\circ} \mathrm{C}$ in core oven to cure them to dark brown colour and cope over the drag matching locating pins is placed.

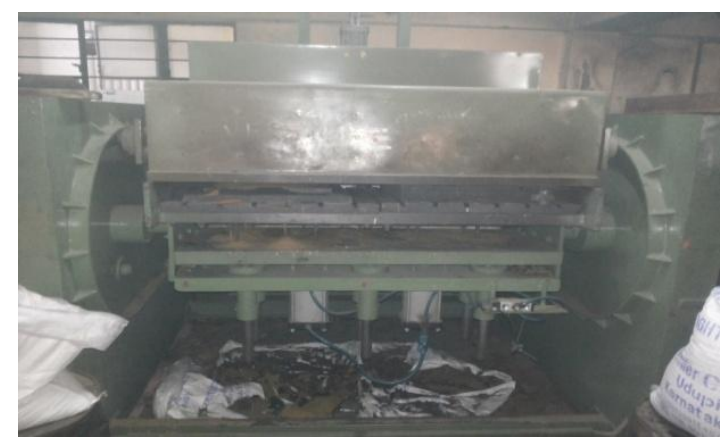

Fig.1. Shell Mould Manufacturing Machine

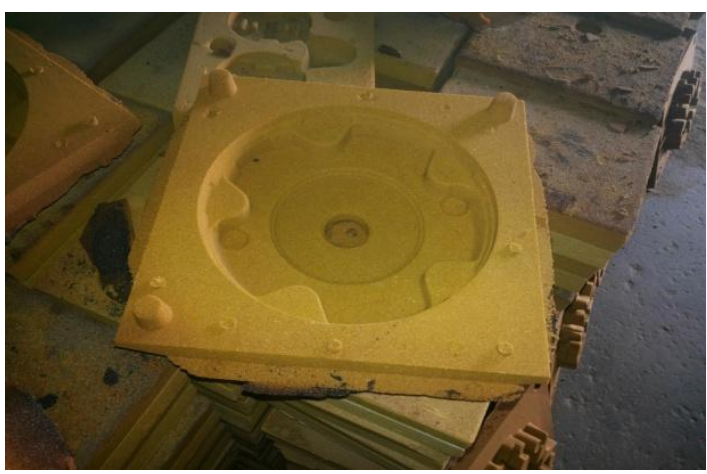

Fig.2 Mould Produced

\subsection{Preparation of Molten Metal}

Molten metal is prepared using CRCA scrap, copper, Ferro manganese, Ferro silicon, inoculants, calcium carbide, and corbocoke as basic raw materials. First charge $40 \quad-50$ Kilograms of Cast Iron Boring to the bottom of the crucible. Switch ON the induction furnace \& charge the Solid Scrap like Foundry Returns, Steel Scrap in orderly manner. Give full Power and keep on poking the Charge with tarsteel \& pig iron for faster melting and for optimum Power utilization. Continue to charge till furnace is $85 \%$ to its total capacity. Required Carburizer, Ferro alloys to be charged as per calculation. Once the molten metal bath attains approx. $1350^{\circ} \mathrm{C}$ take the sample to check the chemistry. Get the Spectro lab report if composition achieved ok top up the furnace by adding returns, otherwise dilute or add Ferro alloy/carburizer to make up the composition, remove the slag using slagger and release the metal for Magnesium treatment.

Magnesium treatment: Take-required percentage of magnesium alloy and inoculation on the quantity of molten metal in the alloy pit of treatment ladle place the tundish cover.

Pour the metal from the furnace to the treatment ladle to get react to the magnesium alloy to convert in to S.G.Iron molten metal. Take the molten metal after treatment for pouring in the same ladle or transferring to $\mathrm{T}$ spout ladle. Do post stream inoculation while pouring \& complete the pouring within the stipulated time to avoid fading of magnesium. Take a sample for microstructure and final chill sample for Spectro analysis.

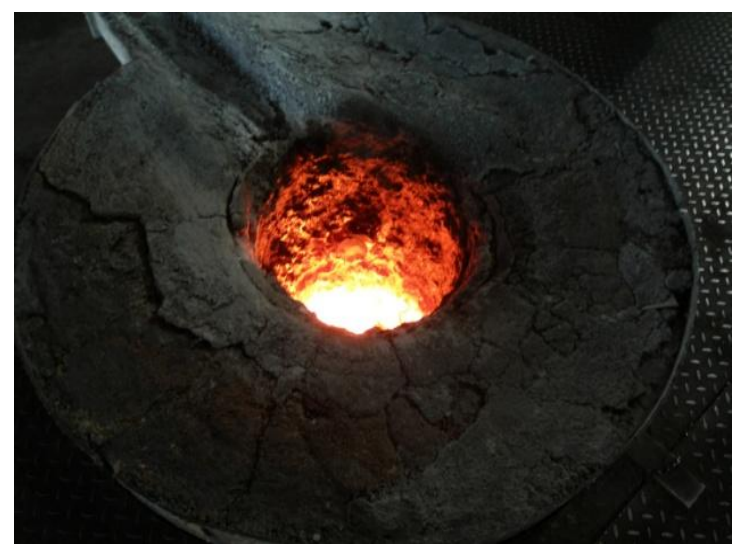

Fig.3 Induction furnace

\subsection{Shakeout and Degating}

The solidified metal component is removed from the mould. This process frees the casting from sand if attached. Degating is the removal of the heads, runners, gates and risers from the casting. Runners, gates and risers can be removed using cutting torches, bandsaws or ceramic cut-off blades. 


\subsection{Inspection and Fettling}

\section{A. First Stage Inspection}

After knocking the castings from the moulds , the moulds are inspected for mismatch, Blow Hole, Shrinkage, Short Pour, Mould leak, Sand drop, Casting bulge, cold Shuts, under cut etc., All castings are shot blasted / sand blasted first stage inspection shall be carried out. On observation of the following defects the castings are identified and reject/reworked. Now-a-days automatic detectors are developed for this purpose [4].

\section{B. Second Stage Inspection}

After $1^{\text {st }}$ stage inspection, Removal of riser neck, ingate area, flow of area and other extra material on the casting is done using hammer \& cutting wheel. The knockout foundry returns shall be moved to respective bin / locations. Second stage inspection will be conducted and defective castings will be reject/reworked.

\section{Fettling}

Inspected castings are ground smoothly to match the casting surface. Grind the parting line completely. Remove defects concerned to shrinkages[7] fins, sticky materials, sand and scaling. Use proper equipments and tools to reduce fettling cost. Under cuts shall be avoided.

\subsection{Finishing}

Finishing of castings is done using three types of CNC machines. 3 main $\mathrm{CNC}$ machines used are horizontal, vertical and Turning CNC. According to the need, castings are allowed to any one machine and finished.

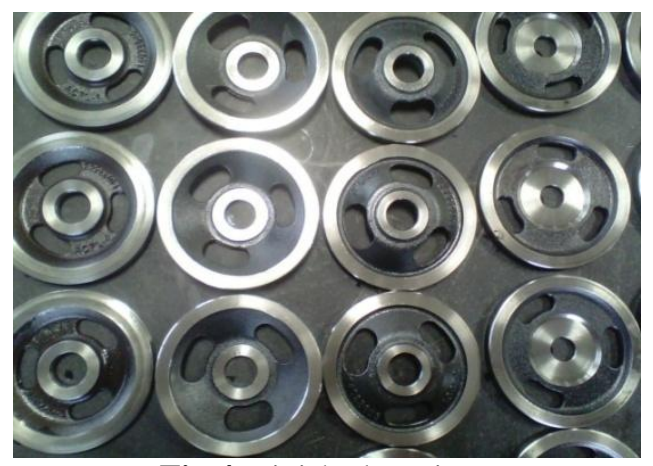

Fig.4. Finished castings

\section{COMPARISON BETWEEN SG 700/2 AND 400/18 GRADE CASTINGS}

As stated earlier this work is carried out considering SG 700/2 grade. Comparison of this with other grade is done in order to study the difference between different grades. For this study another grade is considered for i.e. 400/18 which shows much more deviation from the grade considered.

\subsection{Chemical Composition}

Chemical composition of SG 700/2 Grade is graphically represented as below. Minimum and maximum values of copper, manganese, phosphor, silicon, copper and magnesium is shown. In the same way chemical composition of SG 400/ 18 grade is also shown graphically

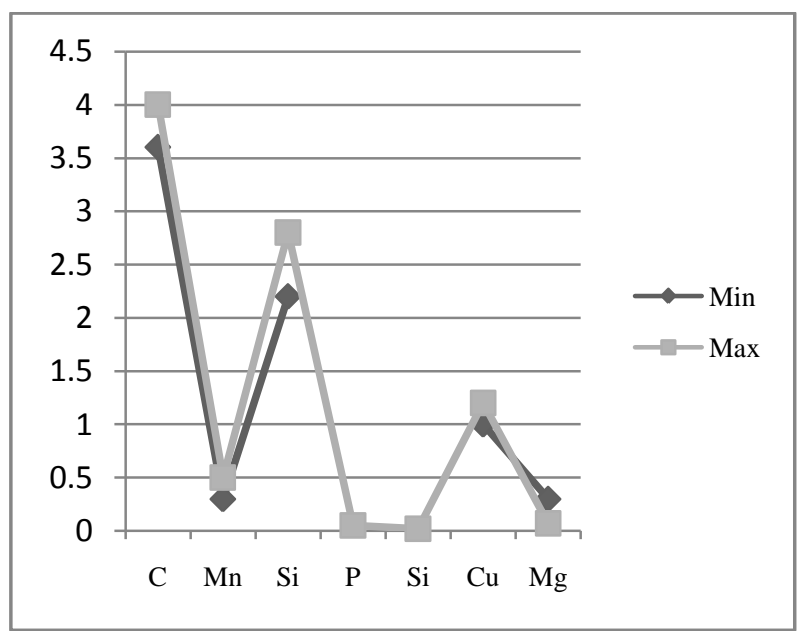

Fig.5. Graphical representation of chemical composition of SG 700/2Grade

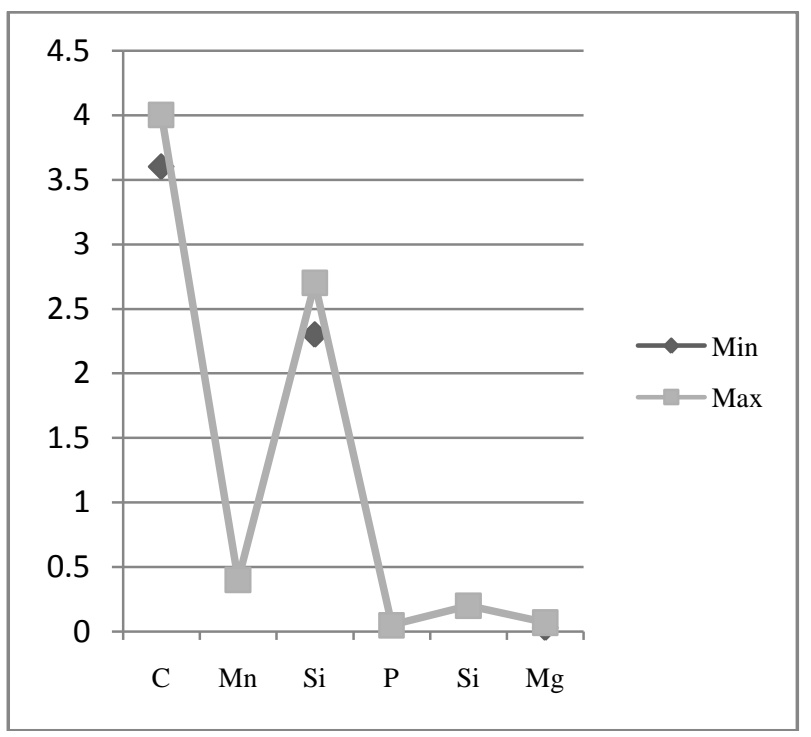

Fig.6. Graphical representation of chemical composition of SG 400/18 grade

\subsection{Mechanical Properties}

Mechanical properties [6] greatly affect the strength and hardness of castings and hence the applications where they can be used. Below two tables shows how mechanical properties differ from grade to grade. 
Table 1. Mechanical Properties of SG 700/2

\begin{tabular}{|l|l|l|l|l|l|}
\hline $\begin{array}{l}\text { HEA } \\
\text { T\# }\end{array}$ & $\begin{array}{l}\text { Yield } \\
\text { Stren } \\
\text { gth }\end{array}$ & $\begin{array}{l}\text { Tensile } \\
\text { Strength(Kg } \\
\text { f/mm }\end{array}$ & $\begin{array}{l}\text { Elonga } \\
\text { tion \% }\end{array}$ & $\begin{array}{l}\text { Reduc } \\
\text { tion \% }\end{array}$ & $\begin{array}{l}\text { Hardness( } \\
\text { BHN) }\end{array}$ \\
\hline MIN & 42.84 & 71.40 & 2 & - & 225 \\
\hline MA & - & - & - & - & 305 \\
X & & & & & \\
\hline
\end{tabular}

Table 2. Mechanical Properties of SG 400/18

\begin{tabular}{|l|l|l|l|l|l|}
\hline $\begin{array}{l}\text { HEA } \\
\text { T\# }\end{array}$ & $\begin{array}{l}\text { Yield } \\
\text { Stren } \\
\text { gth }\end{array}$ & $\begin{array}{l}\text { Tensile } \\
\text { Strength(Kg } \\
\text { f/mm } \text { m }^{2}\end{array}$ & $\begin{array}{l}\text { Elonga } \\
\text { tion \% }\end{array}$ & $\begin{array}{l}\text { Reduc } \\
\text { tion \% }\end{array}$ & $\begin{array}{l}\text { Hardness( } \\
\text { BHN) }\end{array}$ \\
\hline MIN & 28.10 & 42.20 & 18 & - & 143 \\
\hline $\begin{array}{l}\text { MA } \\
\text { X }\end{array}$ & - & - & - & - & 187 \\
\hline
\end{tabular}

\section{RESULTS AND DISCUSSION}

Various parameters are considered and keeping the record of production, Results from the green sand mould process are considered with new process adopted in industry i.e. shell mould process. 1) Increase in the Production rates leads to beneficiary outcomes in any foundry which can be decided by considering Yield of the Process which Was $65 \%$ by green sand mould process and it is increased to $78 \%$ when castings are produced by shell mould process.

Yield can be calculated by using the formula:

$$
\frac{\text { Casting weight }}{\text { Pouring weight }} \times 100
$$

\section{Calculations}

For green sand mould process, consider that $3 \mathrm{~kg}$ molten metal is poured to get castings out of which final castings weighed were of $1.95 \mathrm{~kg}$, if we calculate yield for this calculation is as fallows;

$\frac{1.95}{3}=0.65$, in percentage value we get $65 \%$ yield

In shell mould process as we have little wastage casting weight will be more, usually for a $3 \mathrm{~kg}$ of molten metal, casting weight will be around $2.35 \mathrm{~kg}$. When we calculate yield for the set of castings which gave this readings we get, $2.35=0.7833$, which gives a percentage value of $\frac{78 \%}{3}$

As shape, size, weight of castings produced will be different according to the need it is required to produce different kinds of castings.

These calculations are done considering the same casting in two different processes. It is clear from the calculations that for specified amount of molten metal weight of casting will be more in shell mould process as wastage of metal will be less.

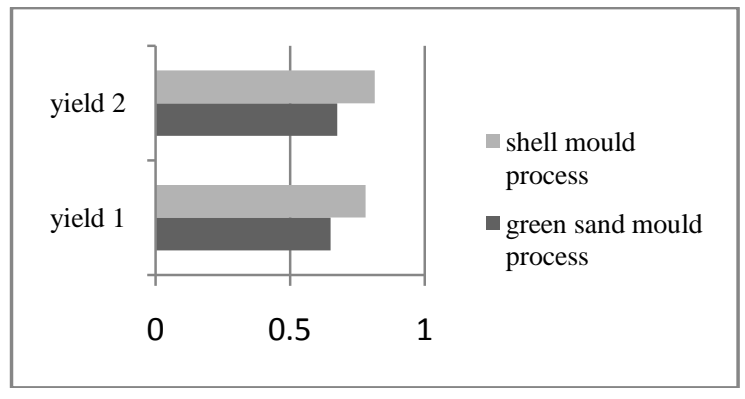

Fig 7. Graphical representation of yield

2) Customers will be satisfied by the timely delivery of castings which can be increased up to $700 /$ month by shell mould process compared to green sand mould process.

This can be justified by the fact that in green sand mould process 1 box gives 4 castings whereas in shell mould process as there will be cakes arranged one above the other usually which contains 10cakes/box which yields 40castings at once.

Green sand mould process:

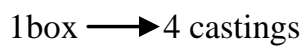

Shell mould process:

$$
1 \text { box } \longrightarrow 10 \text { cakes; } 4 * 10=40 \text { castings }
$$

3) Fine finishing of castings are done using $\mathrm{CNC}$ machines as discussed earlier. Machining time by green sand mould process was $45 \mathrm{~min} /$ piece and now it is only $37 \mathrm{~min} /$ piece so it can be noted that around $8 \mathrm{~min} / \mathrm{pc}$ can be reduced/piece which is a remarkable difference.

Above calculation is done for gear blank. Considerable difference is achieved since the machining allowance provided will be less in case of shell mould process as we get fine finished castings, consider that it is required to produce a casting with $100 \mathrm{~mm}$ thickness, machining allowance given in green sand mould process will be $108 \mathrm{~mm}$ whereas it will be $105 \mathrm{~mm}$ in case of shell mould process.

4) Productivity in kilograms /man/day was 30kilograms by green sand mould process whereas it is $72 \mathrm{kgs}$ by new process adopted which gives huge benefit.

5) Around 3.5\% rejection of castings is achieved adapting shell mould process as it was $8 \%$ before and reduced to $4.5 \%$ later. . Rejection of castings depends upon their hardness, sand drop, volatility, mismatch etc. These problems are very rare in shell mould process and are common in green sand mould process hence rejection rate will be more in green sand mould process. When gear blanks are manufactured and supplied using both processes above difference in rejection level is noticed. 
These results are graphically shown in figure below.

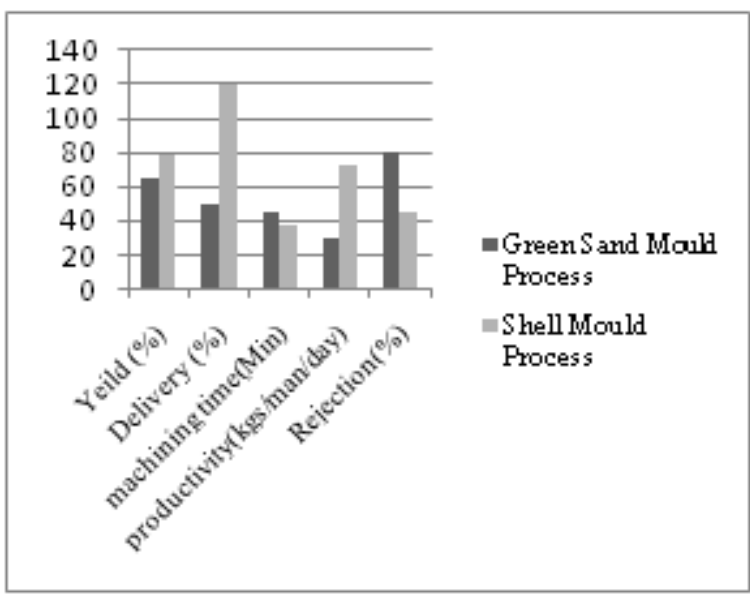

Fig 8.Graphical representation

Apart from these the main raw material used for casting process is sand. Sand metal ratio used in green sand mould process was 1:14 whereas this reduced drastically in case of shell mould process which is $1: 5$ so it can be clearly noticed that around $9 \%$ sand is reduced.

\section{CONCLUSIONS}

This paper provides brief idea about overall change in production parameters of interest in a foundry when casting production is shifted from green sand mould process to shell mould process.

This study was done considering various parameters as discussed above, it is because results of which clears provides how and to what extent various parameters increased which intern have great influence customer satisfaction and hence on profit margins. Effort was made to improve quality, delivery of castings, and yield in a foundry. Apart from these raw materials required for the process is less and also manual work comparatively can be reduced. All these improvements prove to be beneficial for any foundry which wants to survive in competitive market condition as well as to see growth in profit margin.

\section{REFERENCES}

[1]. S. Jones, C.Yuan "Advances in shell Moulding for Investment casting" 2003

[2]. S.Jones, Improved sol based ceramic moulds used for use in investment casting.Ph.D.thesis, University of Birmingham, Edgbaston

[3]. S.Amira, D.Dube, R.Tremblay "Method to Determine Hot Permeability and Strength of Ceramic Moulds"2011

[4]. K. G. Swift, J.D.Booker "Manufacturing process selection handbook"2013
[5]. Wong, B.K.; Sch of Eng.\&Adv. Technol.,Sunderland Univ;Elliot,M.P.;Rapley, C.W. "Automatic casting surface defect recognition and classification"1995

[6]. Nieves, J.; S3Lab., DeustoTechnol.Found., bilbao, spain;; santos,I.;Penya, Y.K,;Rojas, S more authors "Mechanical properties prediction in high precision foundry production" 2009

[7]. Nieves, Javier;S3Lab.,Univ.ofDeusto ,Bilbao, Spain; Santos,I.; Ugrate Pedrero, X.;Bringas, P.G. "Anomoly detection of high precision foundries" 2011 